\title{
АНТИМОНОПОЛЬНОЕ ЗАКОНОДАТЕЛЬСТВО КАК ИНСТРУМЕНТ РАЗВИТИЯ РЫНОЧНОЙ ЭКОНОМИКИ В РОССИИ
}

\section{Статья подготовлена в рамках конференции, посвященной 15-летию Конституции Российской Федерации, принятой на всенародном голосовании 12 декабря 1993 г.}

\begin{abstract}
Аннотация: Принятие Конституции Российской Федеращии заложило соновы рыночной экономики. Одним из эффективных инструментов ее развития в намей стране является антимонопольное, или как его окрестили некоторые авторы, - конкурентное право. Данная статья является небольшим экскурсом в историю становления российского законодательства о защите конкуренции, связывая его развитие напрямую с развитием иивилизованной зрелой рыночной экономики.

Review: The Constitution of the Russian Federation formed the basis for the market economy. Anti-monopoly law (or competition law, as some authors call it) is one of the most efficient instruments for its development in our state. This article provides a brief excursus into the history of formation and development of the Russian legislation on competition protection, and it connects its development directly to the development of a mature market economy.
\end{abstract}

Ключевые слова: Юриспруденция, Антимонопольное, конщентращия, конкуренция

Keywords: jurisprudence, anti-monopoly, concentration, competition.

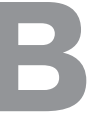
системе государственно-правовых институтов, призванных формировать демократическое правовое социальное государство в нашей стране, ключевое значение имеет принятие 12 декабря 1993 года на всенародном голосовании новой Конституции Российской Федерации, рассчитанной на длительную перспективу и содержащей основные принципы, а также механизмы реализации и защиты социально-экономических, политико-правовых и культурно-духовных интересов народа. Ведь трудно не согласиться с теми специалистами, которые считают что «именно «родовая травма» ядра нашей правовой системы обусловила появление многих проблем, связанных с пробелами и диспропорциями в отечественных конституционно-правовых моделях» ${ }^{1}$.

К фундаментальным конституционным принципам стратегии строительства в России демократического правового социального государства относятся принципы народовластия, народного благосостояния, верховенства Конституции, социально ориентированная рыночная экономика, социальное партнерство, справедливый

${ }^{1}$ Станских С.Н. Кому не выгодна история создания российской Конституции // Конституционное и муниципальное право. 2007. N 5. C. 21. конституционный строй, разделение властей, отбор и оценка кандидатов на государственные и муниципальные должности при помощи открытых конкурсов и сложных экзаменов, проводимых независимыми комиссиями, юридическая ответственность лиц, замещающих государственные и муниципальные должности, за результаты своей деятельности и другие.

Статья 8 Конституции России, устанавливая экономическую основу конституционного строя России, определяет, что в Российской Федерации гарантируются единство экономического пространства, свободное перемещение товаров, услуг и финансовых средств, поддержка конкуренции, свобода экономической деятельности. Названные гарантии являются и принципами рыночной экономики, поскольку исключают возможность всеобъемлющего регулирования государством хозяйственной жизни. Государство, снимая с себя функции организатора, контролера меры труда и потребления, сохраняет за собой лишь функции арбитра между конкурирующими частными субъектами хозяйствования, в задачи которого входит установление общих правил, разрешение споров и борьба с монополистической деятельностью. В главе 1 Конституции «Основы конституционного строя» государство устанавливает исходные принципы для эконо- 


\section{Право и политика $8(164) \cdot 2013$}

мики и гарантии для реализации экономических прав и свобод человека и гражданина. Конституция Российской Федерации определяет основы экономического строя не непосредственно, а через установление экономических прав и свобод (гл. 2) и их гарантий (гл. 1). В этом прослеживается взаимосвязь и взаимообусловленность экономических норм, содержащихся в гл. 1 и в гл. 2 Конституции РФ².

Как упоминалось выше, частью первой статьи 8 Конституции РФ, гарантируется единство экономического пространства, свободное перемещение товаров, услуг и финансовых средств, поддержка конкуренции, свобода экономической деятельности. Кроме того, часть 2 статьи 8 Конституции РФ не допускает экономическую деятельность, направленную на монополизацию и недобросовестную конкуренцию. Таким образом, вышеупомянутые нормы Конституции РФ являются фундаментальными положениями, лежащими в основе российского антимонопольного законодательства.

Представляется необходимым акцентировать внимание на том, что функционирование полноценных рыночных отношений напрямую зависит от возможности свободного входа на тот или иной рынок новых участников, а так же, от соблюдения правил конкуренции самими участниками рынка. При формировании нормативно-правовой базы и правил деятельности участников рынков при поэтапном развитии конкуренции важно учесть и то, что антимонопольное регулирование в рыночной экономике является значительной составляющей. Ориентиром здесь, прежде всего, служат концептуальные положения, закрепленные в Конституции РФ (ч. 1 ст. 8, ч. 2 ст. 34), которые исходят из принципа свободных рыночных отношений и ориентированы на поддержку конкуренции, запрет монополизации и недопущение недобросовестной конкуренции.

По мнению одного из авторитетных ученых в данной области права, К.Ю. Тотьева, целью антимонопольного регулирования является прежде всего установление и реализация правил ведения экономической деятельности на товарных рынках с целью защиты добросовестной конкуренции и обеспечения эффективности рыночных отношений ${ }^{3}$.

По мнению Г.И. Мартыненко, основными целями антимонопольной политики государства являются: формирование единого экономического и правового пространства, обеспечение экономической свободы предпринимательской деятельности, создание конкурентной среды на товарных и финансовых рынках ${ }^{4}$.

${ }^{2}$ Самоненко К.A. «Конституционная составляющая экономических прав и свобод в России: к теории вопроса./ «История государства и права», 2008, N 11 C.3

${ }^{3}$ Тотьев К.Ю. Конкуренция и монополии. М., 1996.

${ }^{4}$ Мартыненко Г.И. «Российское конкурентное законодательство: Новый закон о защите конкуренции»/ «Право и экономика, 2007, №1.
По нашему мнению, цель антимонопольного регулирования в условиях формирующейся российской рыночной экономики представляется гораздо шире и состоит, прежде всего, в формировании единого экономического пространства, обеспечивающего необходимые условия для развития свободы предпринимательской деятельности, конкурентной среды, рыночной дисциплины, а так же в обеспечении защиты более слабой стороны в экономических отношениях - потребителя товаров, работ, услуг тех компаний, которые занимают доминирующее положение на рынке или осуществляющих антиконкурентные действия.

Основой антимонопольного регулирования является нормативно-правовая база, включающая совокупность правовых норм, закрепленных в различных источниках, и направленных в целом на формирование конкурентных отношений и на предупреждение и ограничение правонарушений, связанных с ограничением конкуренции.

В данном аспекте представляется весьма интересным путь развития антимонопольного законодательства в нашей стране, без рассмотрения которого труднее понять суть правовых положений и норм, закрепленных в действующем антимонопольном законодательстве России.

Первый этап российского антимонопольного законодательства связан с принятием в 1991г. Закона РСФСР «О конкуренции и ограничении монополистической деятельности на товарных рынках». Он определял основные цели конкурентной политики, задачи и функции антимонопольных органов, направленные на содействие формированию рыночных отношений на основе развития конкуренции и предпринимательской деятельности, на предупреждение, ограничение и пресечение монополистической деятельности.

Одним из средств осуществления функций надзора и контроля за соблюдением этого закона являлось наделение антимонопольных органов правомочиями возбуждать и рассматривать дела о нарушениях антимонопольного законодательства, принимать обязательные для исполнения хозяйствующими субъектами решения и предписания.

Порядок рассмотрения дел определялся Федеральным антимонопольным органом. Правила рассмотрения дел утверждались неоднократно. При разработке нового антимонопольного закона - Закона «О защите конкуренции» были внесены и реализованы предложения о включении непосредственно в сам Закон норм о порядке возбуждения и рассмотрения дел о нарушении антимонопольного законодательства.

Во многих странах с развитой рыночной экономикой соответствующие нормы имеют форму закона. С учетом опыта зарубежных стран, значимости норм, которые отражали бы особенности порядка возбуждения и рас- 


\section{Системы стабилизации: финансовый контроль}

смотрения дел антимонопольными органами в сочетании с нормами о гласности и гарантиях прав лиц, участвующих в процессе, в новый Федеральный закон «О защите конкуренции» (далее - Закон о защите конкуренции) был включен отдельный раздел о порядке возбуждения и рассмотрения дел о нарушениях антимонопольного законодательства.

Полномочия антимонопольного органа напрямую определялись Законом 1991г.

В июле 1991г. был создан Государственный комитет Российской Федерации по антимонопольной политике и поддержке новых экономических структур, позже - Государственный антимонопольный комитет, в 2003г. преобразованный в Министерство по антимонопольной политике и поддержке предпринимательства, которое, в свою очередь в 2004г. преобразовано в Федеральную антимонопольную службу Российской Федерации (ФАС России).

Правоприменительная практика по фактам нарушений антимонопольного законодательства выявила, что Закон о конкуренции 1991г. не в полной мере отвечает требованиям времени и экономическим процессам в России, и уже в 1993г. стала очевидной необходимость его существенного обновления.

С этого момента начался второй этап - формирование конституционных основ конкурентного законодательства. Конституция РФ гарантирует единство экономического пространства, свободное перемещение товаров, услуг и финансовых средств, поддержку конкуренции. При этом понятие «поддержка конкуренции» трактуется в Конституции РФ в соответствии с Законом о конкуренции 1991г.

Необходимо отметить, что с научной точки зрения, вышеупомянутые конституционные положения о включении непосредственно в текст Основного Закона норм о поддержке конкуренции являются продуманными концептуальными идеями, впервые высказанные выдающимся специалистом в области конституционного права, судьей Конституционного Суда РФ Гаджиевым Гадисом Абдуллаевичем.

Таким образом, с принятием Основного Закона в РФ, были закреплены правовые начала в регулировании конкуренции, заложен правовой фундамент для формирования рыночной экономики.

Третий этап развития конкурентного законодательства начался в 1994г. в связи с принятием нового ГК РФ. Так, часть 2 п. 1 ст. 10 ГК РФ не допускает использование гражданских прав в целях ограничения конкуренции, а также злоупотребление доминирующим положением на рынке.

Изменения конституционного и гражданского законодательства обусловили необходимость внесения изменений и в Закон о конкуренции 1991г.
Четвертый этап - создание новых направлений Закона о конкуренции 1991г.

Ценовое регулирование деятельности хозяйствующих субъектов, доминирующих на рынке, которое в настоящее время реализуется преимущественно в рамках регулирования деятельности субъектов естественных монополий на базе Федерального закона от 17 августа 1995г. N 147-Ф3 «О естественных монополиях», а также специальных законов (например, Федеральный закон «О государственном регулировании тарифов на электрическую и тепловую энергию»).

В целях защиты от недобросовестной конкуренции в области рекламы, предотвращения и пресечения ненадлежащей рекламы в 1995г. был принят Федеральный закон «О рекламе». В настоящее время действует Федеральный закон от 13 марта 2006г. N 38-Ф3 «О рекламе».

Пятый этап - формирование законодательства о защите конкуренции на рынке финансовых услуг (банковских, страховых и иных, связанных с денежными средствами юридических и физических лиц).

Существенные поправки в Закон о конкуренции 1991г. были внесены в 2002г. и воодушевили представителей малого и среднего бизнеса, в значительной степени выводя его из-под опеки чиновников.

Однако особо знаменательным этапом в развитии российского антимонопольного законодательства представляется принятие 26 июля 2006 года ныне действующего Федерального закона «О защите конкуренции» №135-Ф3.

Общие положения действующего антимонопольного законодательства закреплены в Федеральном законе «О защите конкуренции» от 26 июля 2006г. N 135-Ф3 (далее - Закон «О защите конкуренции»), которые направлены как на запрет действий хозяйствующих субъектов, так и на запрет действий федеральных органов исполнительной власти, органов исполнительной власти субъектов Российской Федерации и органов местного самоуправления, направленные на ограничение конкуренции. Важно, что нормы Закона «О защите конкуренции» применяются и к субъектам естественных монополий, если естественные монополисты нарушают антимонопольное законодательство. По существу, в этом Законе объединены два ранее действовавших закона: Закон РСФСР от 22 марта 1991г. N 948-1 «О конкуренции и ограничении монополистической деятельности на товарных рынках» (в ред. от 26 июля 2006г.) и Федеральный закон от 23 июня 1999г. N 117-Ф3 «О защите конкуренции на рынке финансовых услуг» (в ред. от 2 февраля 2006г.).

Кроме положений названных Законов, во многих случаях воспроизведенных без изменений или с небольшими редакционными поправками, Закон со- 


\section{Право и политика $8(164) \cdot 2013$}

держит ряд нововведений. Новый Федеральный закон от 26 июля 2006г. N 135-Ф3 «О защите конкуренции» обозначил новые тенденции отечественного антимонопольного законодательства. Они затронули как содержательную, так и юридико-техническую стороны этой сферы правового регулирования и связаны с усилением функциональности и эффективности правовых норм о защите конкуренции.

По мнению Е.Ю. Борзило, все изменения законодательного регулирования конкурентных отношений с принятием Закона «О защите конкуренции», можно условно разделить на три вида: нормы и институты, вообще не известные ранее российскому антимонопольному законодательству, положения, уточняющие и изменяющие существующие нормы, а также процедурные нормы ${ }^{5}$.

1. Нормы, вообще не известные ранее российскому антимонопольному законодательству. К ним можно отнести в том числе нормы, касающиеся порядка предоставления государственной помощи, а также коллективное доминирование.

2. Положения, уточняющие и изменяющие существующие нормы. К таким положениям можно отнести, в частности, уточнение сферы действия закона, сформулированные определения согласованных действий и антиконкурентной координации, а также изменения качественных и количественных порогов для определения сделок, связанных с экономической концентрацией. Последние заслуживают отдельных комментариев. Правила контроля за экономической концентрацией претерпели некоторые изменения. Эти изменения, будучи не слишком значительными, тем не менее имеют существенную практическую ценность.

Характерно, что виды антимонопольного контроля за экономической концентрацией не изменились: попрежнему существует предварительный и последующий контроль. Не изменились существенно и виды сделок, требующих согласования с антимонопольными органами. Это по-прежнему слияния, присоединения, создание коммерческих организаций, а также приобретение акций, основных производственных средств, нематериальных активов и прав контроля.

Однако количественные пороги этих сделок изменены: если ранее согласования с антимонопольным органом требовало приобретение более $10 \%$ основных производственных средств и/или нематериальных активов, то теперь этот порог увеличен до $20 \%$.

Значительно облегчено совершение сделок по приобретению акций/долей. Ранее действовавшее конкурентное законодательство устанавливало обязанность

${ }_{5}^{5}$ Борзило Е.Ю. «Новое в российском антимонопольном законодательстве» / «Вестник гражданского права», 2006, №2. С. 14. получения согласования на приобретение доли участия в уставном капитале более 20\%. Впоследствии Высший Арбитражный Суд Российской Федерации разъяснил, что предварительное согласие антимонопольного органа на приобретение акций хозяйственного общества с правом голоса необходимо и в тех случаях, когда приобретатель уже имел в своем распоряжении более $20 \%$ указанных акций 6 .

Теперь с предварительного согласия антимонопольного органа субъектами антимонопольного контроля совершается приобретение акций, если доля голосующих акций становится выше 25\%, 50\%, 75\%, и приобретение долей в обществах с ограниченной ответственностью, если при этом размер доли в уставном капитале становится более $1 / 3-50 \%-2 / 3$.

Дополнены и частично изменены критерии определения лиц, чьи сделки совершаются с предварительного согласия антимонопольных органов.

3. Процедурные нормы. Изменены сроки и порядок рассмотрения ходатайств и уведомлений, подаваемых в антимонопольный орган для согласования сделок, связанных с экономической концентрацией, согласительный порядок осуществления сделок экономической концентрации внутри группы лиц заменен на уведомительный (ст. 31 нового Закона). В Закон также полностью включены процедурные правила рассмотрения дел о нарушении антимонопольного законодательства, которые ранее регулировались ведомственным актом - приказом антимонопольного органа. При этом какие-либо коренные изменения процедура рассмотрения не претерпела.

Этот краткий обзор изменений в антимонопольном законодательстве, несомненно, может являться предметом отдельного исследования, посвященного теме генезиса основных начал российского антимонопольного законодательства, однако объем научной статьи не позволяет комплексно подойти к анализу вышеуказанных вопросов.

Подводя итог вышесказанному, представляется необходимым сделать вывод о том, что российское антимонопольное законодательство является логически обоснованным исторически сложившимся постоянно развивающимся институтом, призванным гарантировать и развивать установленные в Конституции РФ положения об обеспечении в стране единства экономического пространства, свободного перемещение товаров, услуг и финансовых средств, поддержке конкуренции и свободы экономической деятельности.

\footnotetext{
${ }^{6}$ Пункт 22 информационного письма Высшего Арбитражного Суда Российской Федерации от 30.03.1998 N 32 «Обзор практики разрешения споров, связанных с применением антимонопольного законодательства».
} 
DOI: $10.7256 / 1811-9018.2013 .8 .1180$

При цитировании этой статьи сноска на dоі обязательна

Системы стабилизации: финансовый контроль

\section{Библиография:}

1. Борзило Е.Ю. «Новое в российском антимонопольном законодательстве» / «Вестник гражданского права», 2006, №2. С. 14.

2. Мартыненко Г.И. «Российское конкурентное законодательство: Новый закон о защите конкуренции»/ «Право и экономика, 2007, №1.

3. Самоненко К.А. «Конституционная составляющая экономических прав и свобод в России: к теории вопроса./ «История государства и права», 2008, N 11 С.3

4. Станских С.Н. Кому не выгодна история создания российской Конституции // Конституционное и муниципальное право. 2007. N 5. С. 21.

5. Тотьев К.Ю. Конкуренция и монополии. М., 1996

\section{References (transliteration):}

1. Borzilo E.Yu. «Novoe v rossiyskom antimonopol'nom zakonodatel'stve» / «Vestnik grazhdanskogo prava», 2006, №2. S. 14.

2. Martynenko G.I. «Rossiyskoe konkurentnoe zakonodatel'stvo: Novyy zakon o zaschite konkurencii»/ «Pravo i ekonomika, 2007, №1.

3. Samonenko K.A. «Konstitucionnaya sostavlyayuschaya ekonomicheskih prav i svobod v Rossii: k teorii voprosa./ "Istoriya gosudarstva i prava", 2008, N 11 S.3

4. Stanskih S.N. Komu ne vygodna istoriya sozdaniya rossiyskoy Konstitucii // Konstitucionnoe i municipal'noe pravo. 2007. N 5. S. 21.

5. Tot'ev K.Yu. Konkurenciya i monopolii. M., 1996 